\title{
Diálogo Entre a Química e a Arqueologia: Análise de Artefactos Cerầmicos por Cromatografia Gasosa
}

\author{
César Oliveira \\ Centro de Química, Departamento de Química da Universidade do Minho, Braga \\ cesar@quimica.uminho.pt
}

\begin{abstract}
Dialogue between Chemistry and Archaeology - Gas chromatographic analysis of ceramic artifacts - discoveries in the mouth of Peralto stream (Esposende, Northern Portugal) revealed traces of Roman occupation along the Iberian Atlantic coast. Among them were found a large number of ceramic container fragments from Baetica region (ancient Roman province in Hispania under the influence of the Guadalquivir River basin, nowadays Andaluzia) from a shipwreck dating from the time of Augustus. Some questions were raised about the type of cargo in the ship. The discovery was an opportunity for an exciting and fruitful collaboration between chemists and archaeologists. ${ }^{1}$ This paper presents some introductory concepts on the chemical analysis of ceramic artifacts.
\end{abstract}

Algumas descobertas arqueológicas no sítio da foz da ribeira do Peralto (Esposende, Norte de Portugal) evidenciaram a presença de vários testemunhos de ocupação romana ao longo da costa ibérica Atlântica. De estre estes destaca-se um elevado número de fragmentos de cerâmica da região Bética (antiga província Romana na Hispania sob a influência da bacia do rio Guadalquivir, localizada aproximadamente no território da actual província da Andaluzia) de contentores de diferentes tipologias, com origem num naufrágio datado da época de Augusto. Esta descoberta levantou diversas questões sobre o tipo de carga transportado por esta embarcação, tendo representado uma oportunidade para uma estreita colaboração entre químicos e arqueólogos. ${ }^{1}$ Neste artigo apresentam-se alguns conceitos introdutórios importantes na análise química de artefactos cerâmicos.

\section{INTRODUÇÃO}

No sítio da foz da ribeira do Peralto (Marinhas, Esposende, Norte de Portugal) têm sido encontrados achados arqueológicos que evidenciam a presença e a ocupação romanas ao longo da costa atlântica. De entre eles, destaca-se um número elevado de fragmentos de cerâmica Bética (antiga província Romana na Hispânia sob a influência da bacia do rio Guadalquivir, aproximadamente a Andaluzia dos nossos dias) provenientes de um naufrágio datado da época de Augusto e recolhidos, em 2005, na faixa da baixa mar de Rio de Moinhos, em Esposende. Na grande maioria predominam as ânforas da tipologia Haltern 70 (Figura 1), alguns fragmentos de ânforas de produção gaditana do tipo Dressel 7-11 e de ânforas do Guadalquivir de tipo Urceus (Figura 2). Os materiais cerâmicos encontrados neste naufrágio permaneceram alguns anos sem estudo até que...

O autor iniciou os trabalhos na análise química de artefactos arqueológicos por um mero acaso. Já com alguns anos de experiência na aplicação de técnicas cromatográficas à análise de matrizes orgânicas complexas, foi contactado em finais de 2011 por um arqueólogo, Rui Morais, na altura docente no Departamento de História da Universidade do

\footnotetext{
1 Comemora-se este ano o segundo milénio da morte de Gaius Iulius Caesar Octavianus Augustus (César Augusto), o primeiro imperador romano, considerado o fundador de Bracara Augusta (actual cidade de Braga). Numa organização conjunta dos municípios de Braga e Esposende celebrou-se entre 10 e 12 de Setembro o "Bimilenário de Augusto", que incluiu o Simpósio Internacional "Chromatography and DNA Analysis in Archaeology”.

Contactos: bimilenario.augusto2014@gmail.com
}

Minho. Tinha na sua posse material cerâmico proveniente de um naufrágio romano - um bico fundeiro de uma ânfora Haltern 70 com um extenso depósito de material orgânico no seu interior (Figura 1) e um bordo de ânfora Urceus (Figura 2), que ao contrário da primeira não apresentava quaisquer vestígios de resíduos orgânicos visíveis a olho nu. Sabendo que trabalhava em cromatografia, pretendia que efectuasse a análise aos dois fragmentos cerâmicos para perceber qual o conteúdo original destas ânforas. Iniciou-se nesse momento um desafio, uma aventura ao estilo policial, uma aplicação muito directa e concreta da Química. Teria de elaborar uma metodologia de extracção dos compostos orgânicos dos materiais cerâmicos e proceder à sua análise por cromatografia gasosa com detecção por massa. No decorrer das pesquisas efectuadas foi constatada a existência de apenas um pequeno número de grupos de investigação europeus a trabalhar na área, assim como a ausência de trabalhos publicados em Portugal.

\section{As ARGILAS}

Para os arqueólogos, a tipologia e a análise macroscópica das argilas foi durante muito tempo o principal meio de identificação das peças estudadas. Todavia, uma simples análise macroscópica a olho nu ou à lupa binocular poderá não ser suficiente para distinguir a origem das cerâmicas, pelo que o conhecimento das propriedades físicas, mineralógicas ou químicas das argilas pode permitir a obtenção de informações preciosas. Este foi durante bastante tempo o principal ponto de contacto entre a Química e a Arqueologia, com a aplicação de técnicas de análise estrutural como a difracção de raios X ou a Microscopia Electrónica 


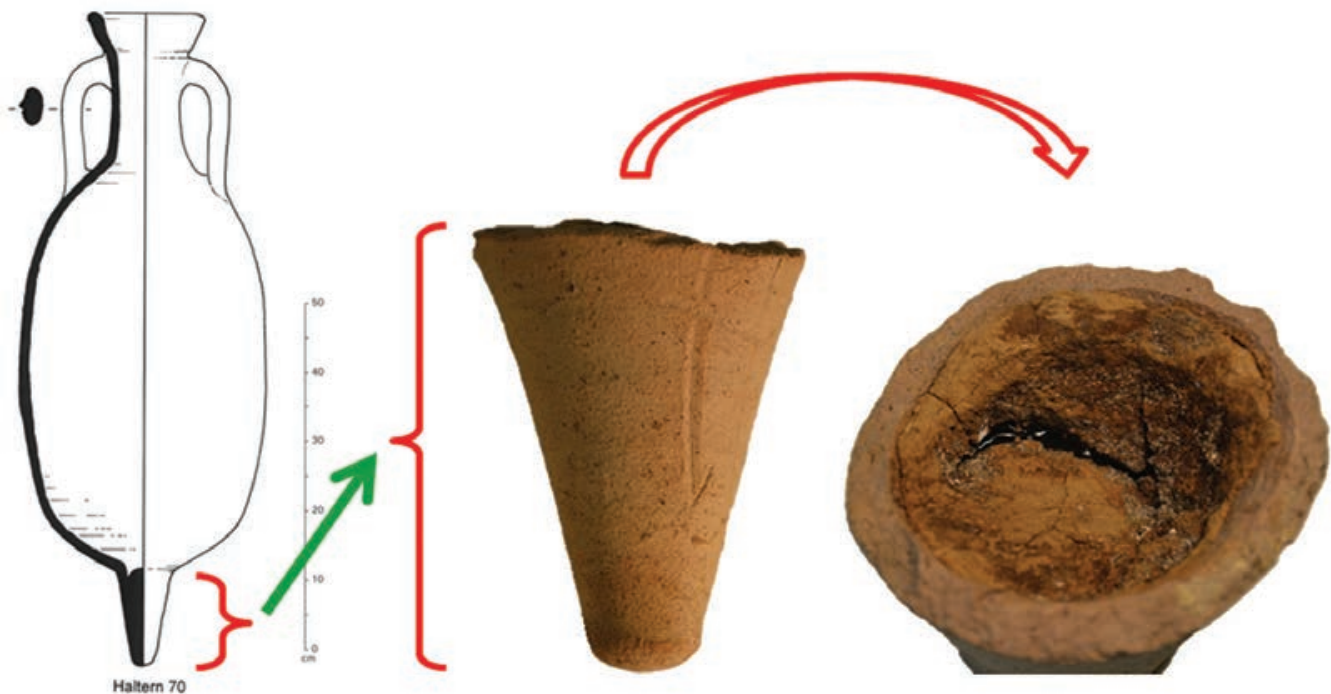

Figura 1 - a) Esquema de uma ânfora Haltern 70; b) vista lateral do bico fundeiro exibindo a marca característica do oleiro; c) vista superior do bico fundeiro, apresentado extenso depósito de material orgânico

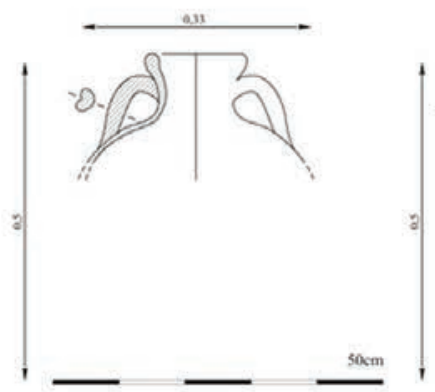

Tipo Urceus 1

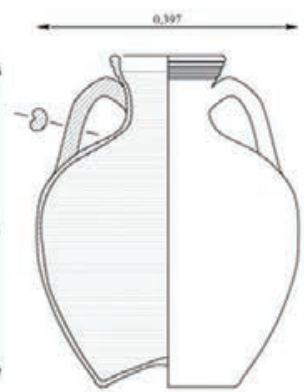

Tipo Urceus 2

Capacidade: $3,2 \mathrm{~L}$
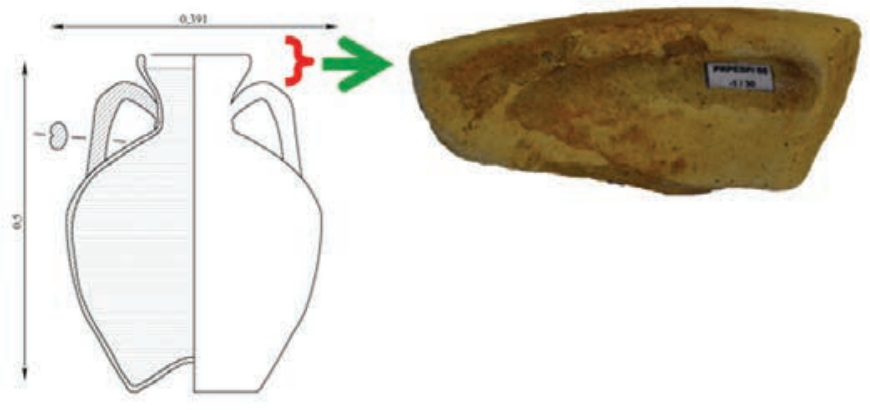

Tipo Urceus 3

Capacidade: $2,8 \mathrm{I}$

Figura 2 - a) Esquema de três tipologias de ânforas Urceus; b) vista do bordo de ânfora, aparentemente sem vestígios de material orgânico

de Varrimento. Um dos objectivos da aplicação destas técnicas é o estudo da composição química das pastas e dos seus processos de cozedura, o que em alguns casos permitirá identificar os barreiros de onde foram extraídas as argilas e os locais de produção das cerâmicas. Estes, por uma questão de economia de custos deveriam encontrar-se na proximidade das áreas de produção dos bens consumíveis (vinho, azeite, preparados piscícolas), pelo que a sua identificação permitirá conhecer as rotas comerciais desde os locais de produção das ânforas até aos centros consumidores onde são encontrados os fragmentos cerâmicos. Durante décadas este tipo de informação química foi a única disponível para os arqueólogos. Contudo, embora extremamente importantes, estas técnicas analíticas fornecem informações indirectas sobre o conteúdo original dos contentores cerâmicos. Torna-se por isso imperativo proceder à análise química dos vestígios orgânicos ainda presentes nas cerâmicas.

\section{AlgUMAS PROPRIEDADES DAS ARGILAS}

As cerâmicas são obtidas pela moldagem, secagem e cozedura de argilas. Quimicamente dá-se o nome de argila ao conjunto de minerais constituídos maioritariamente por silicatos de alumínio hidratados $\left(2 \mathrm{SiO}_{2} \cdot \mathrm{Al}_{2} \mathrm{O}_{3} \cdot 2 \mathrm{H}_{2} \mathrm{O}\right)$ denominados caulim ou caulinite. Geologicamente, as argilas são solos residuais ou sedimentares que se formam em consequência da degradação física e/ou química de rochas cristalinas e sedimentares.

A argila usada na produção de cerâmica é uma mistura de vários minerais (caulinite, ilite, montemorilonite) com uma estrutura granular de grãos com dimensões reduzidas inferiores a $4 \mu \mathrm{m}$, sendo facilmente moldável quando em contacto com a água e adquirindo dureza e estabilidades química e física quando cozida a uma temperatura suficientemente elevada. Normalmente apresentam uma estrutura laminar, com superfícies específicas elevadas, apresentando-se carregadas negativamente nas faces e positivamente nos bordos. Os grãos da argila absorvem ou perdem água com facilidade, expandindo-se ou contraindo-se, podendo cada partícula de argila absorver várias camadas de moléculas de água, e juntamente com esta, compostos orgânicos solúveis (Figura 3). As espécies orgânicas, uma vez absorvidas, encontram-se imobilizadas entre as camadas de argila, minimizando o contacto com a atmosfera oxidante e re- 
duzindo os processos de degradação natural dos materiais orgânicos durante o período pós-deposicional. Desta forma as argilas apresentam “memória” por preservarem na sua estrutura vestígios do conteúdo original destes contentores.

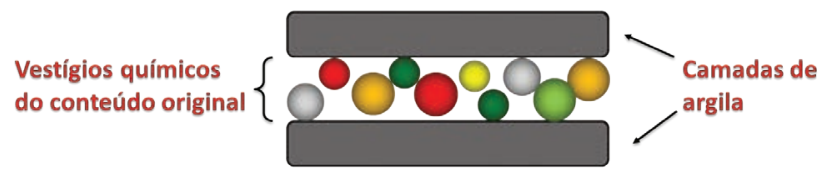

Figura 3 - Representação de duas camadas de argila contendo material orgânico preservado entre camadas

\section{RESÍDUOS ORGÂNICOS PRESENTES NAS CERÂMICAS}

As espécies absorvidas nas argilas são imobilizadas por interacções fracas entre as camadas da argila, podendo ser facilmente lixiviadas na presença de água ou de outros solventes. Por isso, a deposição de peças em locais húmidos ou alagados origina a perda por lixiviação dos compostos orgânicos solúveis, dificultando a sua análise química. Todavia, nalguns casos, é possível encontrarem-se preservadas na estrutura das argilas substâncias orgânicas provenientes dos líquidos com os quais estiveram em contacto. No caso particular de contentores destinados ao transporte de líquidos, é frequente a impermeabilização destes com uma fina camada de material resinoso, normalmente resina de pinheiro. Esta, por ser hidrofóbica actua como agente impermeabilizador, impedindo também que o oxigénio penetre através das paredes cerâmicas e oxide a matriz orgânica.

Os resíduos orgânicos presentes nestes materiais podem estar presentes em diferentes formas: i) o conteúdo orgânico preservado (em casos muito raros encontram-se vasos ainda inviolados, com o conteúdo intacto); ii) perduram resíduos orgânicos visíveis na superfície cerâmica interior ou exterior dos vasos (muito frequente nas cerâmicas revestidas a material resinoso); ou iii) encontram-se resíduos preservados entre as camadas de argila das paredes dos vasos, que são invisíveis a olho nu [1].

As maiores dificuldades analíticas não se devem apenas à complexidade química dessas substâncias naturais e às suas misturas, mas também às alterações da composição química original provocadas por actividades como a cozedura e o aquecimento [2]. A estas acrescente-se a influência das condições de enterramento do material cerâmico (por exemplo, meio envolvente seco/húmido ou anaeróbio/oxidante), procedimentos inadequados de recolha, limpeza ou armazenamento, que podem induzir alterações adicionais a estes materiais orgânicos por contaminação química e/ou eliminação de vestígios orgânicos, comprometendo desta forma a sua análise [2].

\section{ALGUNS EXEMPLOS DE MATRIZES ORGÂNICAS}

A degradação natural dos compostos orgânicos conduz a uma miríade de alterações possíveis da matriz orgânica inicial. No caso de fragmentos de contentores cerâmicos estas modificações são acrescidas da possibilidade de reu- tilização dos mesmos em funções distintas das iniciais. Por exemplo, um contentor inicialmente utilizado para vinho pode, depois de vazio, ter sido empregue para azeite dando origem a uma mistura de traçadores moleculares provenientes de matrizes orgânicas diferentes. A acrescer a estas dificuldades existe também a possibilidade de contaminação dos fragmentos cerâmicos durante o processo de deposição (por exemplo por lixiviação de camadas superiores ricas em material orgânico) ou uma reduzida concentração dos resíduos orgânicos, o que dificulta grandemente a tarefa de análise e a obtenção de conclusões fiáveis.

Os resíduos orgânicos presentes nas cerâmicas podem ter origem em diferentes tipos de matrizes orgânicas:

Resinas: Dada a porosidade dos materiais argilosos é frequente o uso de resinas na impermeabilização de contentores cerâmicos usados no transporte ou armazenamento de líquidos. A aplicação das resinas ocorre a temperaturas elevadas por forma a diminuir a viscosidade destas e aumentar a sua capacidade de penetração na argila. As elevadas temperaturas de aquecimento alteram a sua composição química por promoverem reacções de aromatização, desmetilação e descarboxilação dos compostos terpenóides, originando novas moléculas de massa molecular mais reduzida (Figura 4).

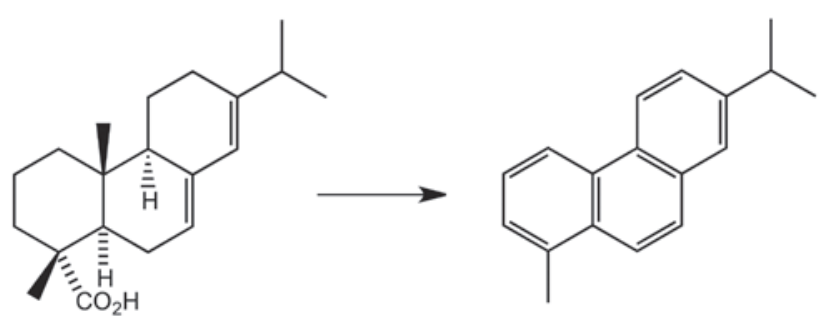

Figura 4 - Transformação do ácido abiético em reteno pelo aquecimento de resinas naturais

Como exemplos de compostos característicos da presença de resinas pode referir-se os ácidos abiético, pimárico, isopimárico e 7-oxodesidroabiético. Em geral, os monoterpenos como o $\alpha$-pineno, canfeno, $p$-cimeno, limoneno e borneol são compostos predominantes em resinas naturais. Os compostos aromáticos, como o reteno, são característicos de resina de pinheiro. Pensa-se que estes revestimentos não seriam empregues em contentores destinados a líquidos mais viscosos, como o azeite [3].

Uvas/vinho: Os ácidos tartárico e gálico são biomarcadores característicos da presença de vinho e/ou uvas, embora estejam presentes também em várias plantas. O ácido gálico, por exemplo, pode ser encontrado em folhas de chá e na casca de carvalho. Um bom indicador químico da presença de vinho tinto é a malvidina, uma antocianina estável ao longo do tempo, responsável pela cor vermelha das uvas e vinhos. Contrariamente ao ácido tartárico, a malvidina está presente em algumas outras plantas, sendo a mais importante a romã, uma fruta popular no Médio Oriente onde o sumo desta era por vezes adicionado ao vinho. A solubilidade da malvidina em água diminui com o aumento do grau de polimerização dos resíduos orgânicos, favorecendo a 
preservação desta em materiais arqueológicos [4]. Quando em ambiente fortemente alcalino, a malvidina liberta ácido siríngico - outro marcador importante do vinho tinto [5].

Azeite: $\mathrm{O}$ azeite é composto por uma mistura de triacilgliceróis, fosfolípidos e triacilgliceróis oxidados. Os ácidos insaturados mais abundantes são o oleico $\left(\mathrm{C}_{18: 1}\right)$, cuja presença distingue o azeite de outros óleos naturais, o linoleico $\left(C_{18: 2}\right)$ e o linolénico $\left(\mathrm{C}_{18: 3}\right)$, enquanto o palmítico $\left(\mathrm{C}_{16: 0}\right)$ e o esteárico $\left(\mathrm{C}_{18: 0}\right)$ são os ácidos saturados mais abundantes (Figura 5). Além dos triglicéridos, o azeite contém também pequenas quantidades de fosfolípidos, pigmentos, hidratos de carbono, proteínas, esteróis e compostos resinosos. Estão também presentes substâncias com propriedades antioxidantes como os tocoferóis e compostos fenólicos, nomeadamente os ácidos cafeico e ferúlico. A identificação de vestígios de azeite em fragmentos cerâmicos é dificultada pela degradação dos compostos lipídicos por reacções de oxidação. Nestas condições os ácidos palmítico e esteárico são mais resistentes ao ataque químico relativamente aos ácidos insaturados linoleico e linolénico [6]. Nalguns casos a quantificação de compostos voláteis como os sesquiterpenos $\alpha$-muuroleno ou $\alpha$-copaeno permite discriminar a área de produção do azeite, estando os níveis destes dependentes das condições geográficas ou climáticas e da existência de doenças características que afectem as oliveiras [7].
O mel, sendo um produto natural não possui uma composição totalmente definida, encontrando-se esta dependente de factores diversos como o tipo de pólen recolhido pelas abelhas, clima, condições ambientais e sazonais ou particularidades do seu manuseamento e processamento.

\section{TRAÇADORES MOLECULARES}

Apesar de poderem sofrer alterações físicas, químicas ou microbianas, algumas das substâncias orgânicas são relativamente estáveis ao longo do tempo ou decompõem-se através de mecanismos conhecidos, dando origem a compostos cuja detecção permite reconstituir a composição inicial do material orgânico. Os traçadores ou marcadores moleculares são compostos químicos cuja presença é característica de uma única fonte emissora ou de um número reduzido de fontes conhecidas (alguns exemplos na Tabela 1). Idealmente são compostos estáveis na natureza, apresentando relações directas com a sua fonte. Dado o elevado tempo de permanência dos artefactos arqueológicos em solos húmidos ou submersos, estes compostos devem também apresentar baixa solubilidade em água de forma a não serem facilmente lixiviados.

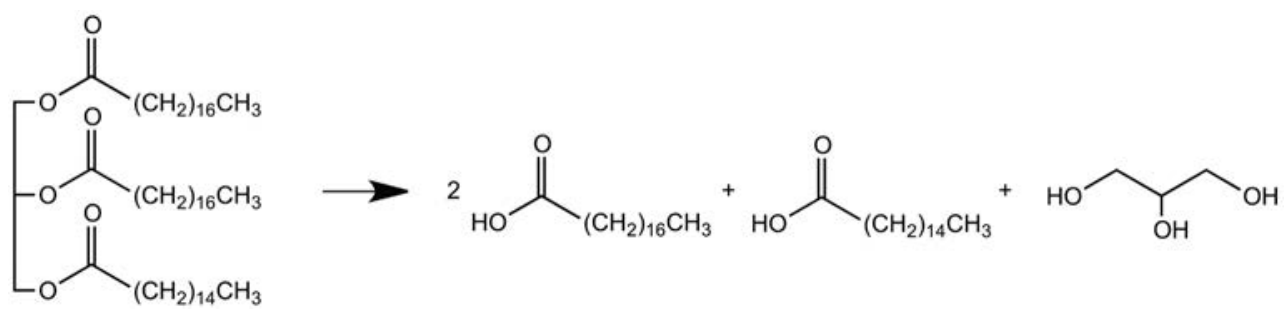

Figura 5 - Formação de ácidos gordos $C_{16: 0}$ e $C_{18: 0}$ por hidrólise de triacilgliceróis presentes no azeite

Mel: o mel contém cerca de duzentas substâncias diferentes, apresentando elevadas quantidades de monossacarídeos como a frutose, glucose e sacarose e quantidades menores de dissacarídeos, trissacarídeos e tetrassacarídeos [8]; cerca de 0,57\% de ácidos orgânicos como o glucónico, resultante da digestão enzimática da glucose, pirúvico, málico, cítrico, succínico e fumárico; minerais; vitaminas; proteínas; aminoácidos como a prolina (dominante), arginina, triptofano e cisteína; lípidos e compostos fenólicos como os ácidos gálico, p-cumárico, cafeico, elágico, ferúlico, clorogénico, siríngico, cinâmico, vanílico e $p$-hidroxibenzóico [9]. Um dos compostos característicos do mel é o hidroximetilfurfural que é formado tanto pela desidratação de hexoses em meio ácido como por reacções entre os aminoácidos ou proteínas e os hidratos de carbono [10]. As temperaturas elevadas ou armazenamentos prolongados podem aumentar o nível de hidroximetilfurfural no mel [11].
A identificação de traçadores moleculares permite relacionar o conjunto de compostos orgânicos determinados, uma espécie de impressão digital química, com os compostos ou misturas destes que estiveram na sua origem. Por exemplo, o levoglucosano (Figura 6) é um indicador da presença de celulose proveniente da queima de espécies lenhosas (em fogos ou na confecção de alimentos) e os ácidos $n$-tetradecanóico, $n$-hexadecanóico, $n$-octadecanóico e cis-octadec-9-enóico podem estar relacionados com as emissões resultantes da cozedura de carnes. Por exemplo, o mel pode ser caracterizado pela presença de monoésteres de cadeia longa (40 a 52 átomos de carbono) com número par de átomos de carbono, alcanos lineares com número ímpar de átomos de carbono $\left(\mathrm{C}_{21}\right.$ a $\left.\mathrm{C}_{33}\right)$ e ácidos gordos saturados com número par de átomos de carbono $\left(\mathrm{C}_{22}\right.$ a $\left.\mathrm{C}_{34}\right)$.

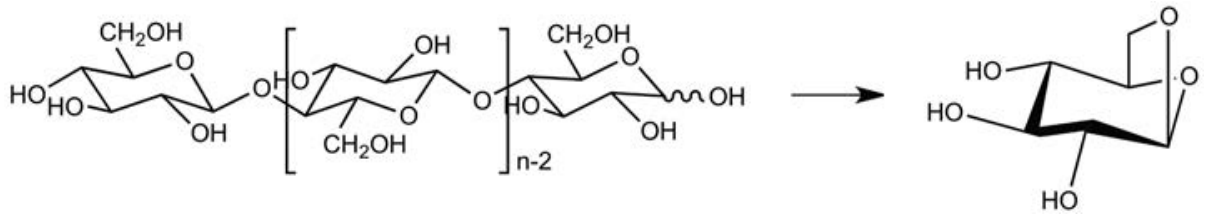

Figura 6 - Degradação térmica da celulose com produção de levoglucosano 
Tabela 1 - Alguns marcadores de resíduos orgânicos

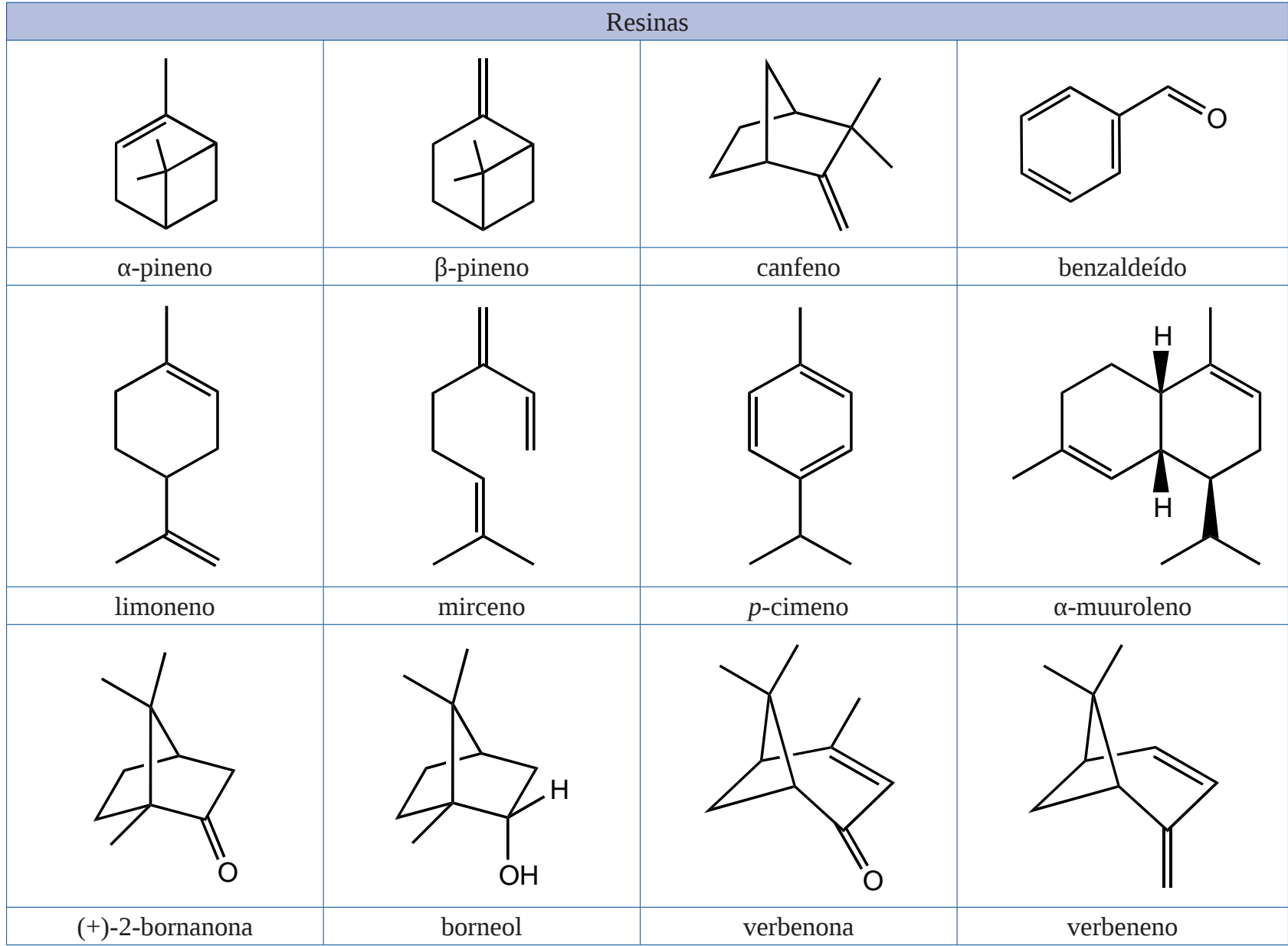

(n)

- continua - 
- continuação -

malvidina

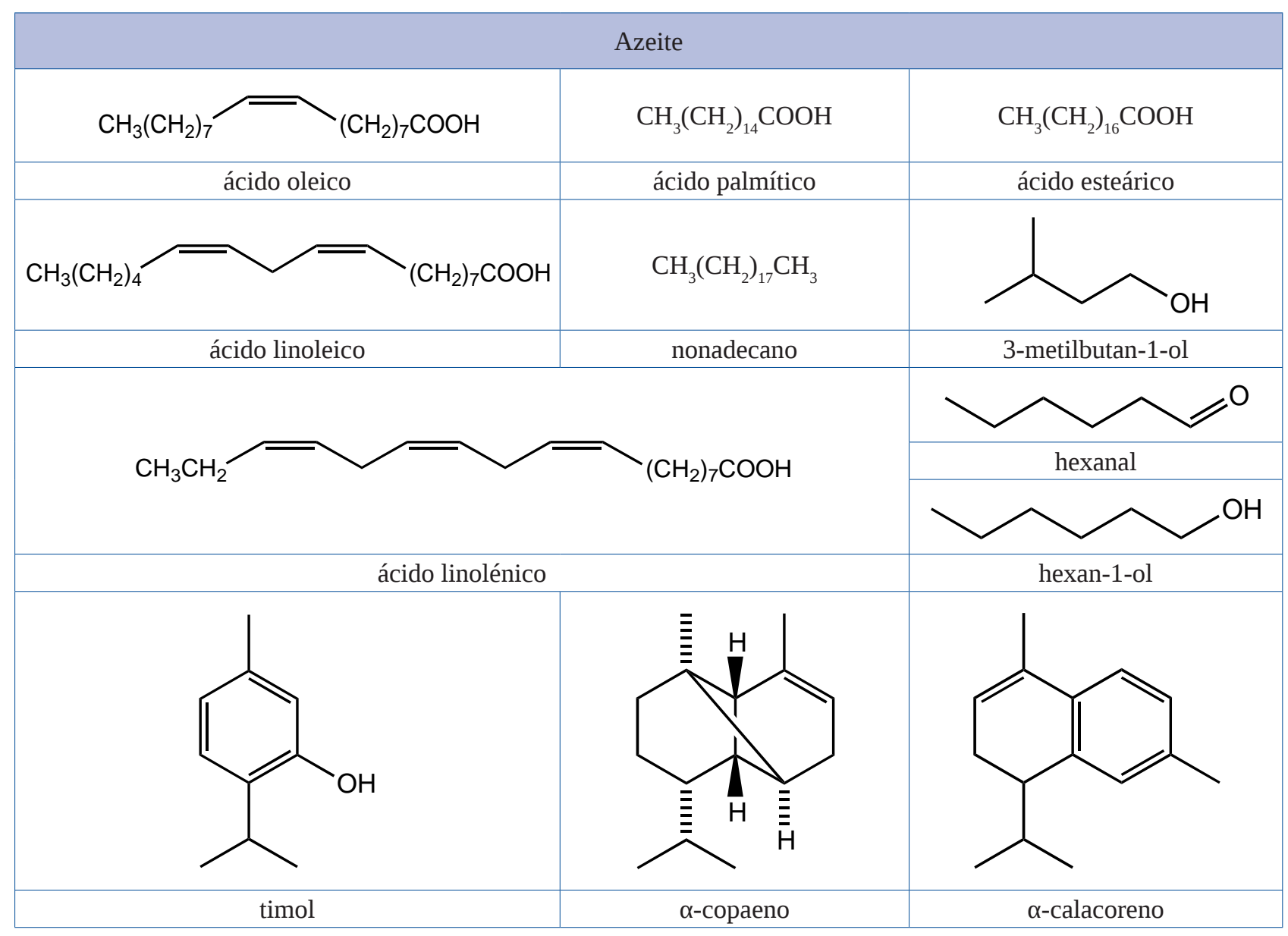

\section{VOLTANDO AOS DOIS FRAGMENTOS CERÂMICOS QUE ORIGINA- RAM ESTE TRABALHO, QUE CONCLUSÕES SE TIRARAM?}

Iniciou-se a investigação pela análise ao bico fundeiro de ânfora Haltern 70, por se acreditar que o extenso depósito de material orgânico facilitaria o estudo. Triturou-se uma porção do resíduo e extraiu-se o material orgânico num aparelho Soxhlet. O cromatograma do extracto orgânico revelou um elevado número de bandas de intensidade elevada não resolvidas. Estas, provenientes maioritariamente de compostos resinosos, encontravam-se sobrepostas o que mascarava a presença de compostos de intensidade mais reduzida. Efectuou-se uma nova extracção seguida de uma coluna flash, dando origem a 20 fracções estudadas individualmente (Figura 7). O bordo de ânfora Urceus, que pensávamos ser de análise mais difícil por não apresentar resíduos orgânicos visíveis, não levantou grandes problemas.

\section{OS PRIMEIROS RESULTADOS}

Para além de numerosos compostos de origem resinosa, da análise ao bico fundeiro de ânfora Haltern 70 resultaram compostos característicos da presença de vinho como o 4-etilguaiacol e o 4-etilcatecol, assim como aldeídos fenólicos cuja presença poderia estar associada à degradação da lignina da madeira pelo álcool, tendo-se colocado a hipótese do vinho ter permanecido algum tempo em recipientes de madeira antes de transferido para a Haltern 70. Os resultados obtidos pareciam conduzir esta ânfora para o transporte de vinho. Contudo, a estes grupos de traçadores químicos juntaram-se compostos característicos de óleos naturais (sesquiterpenos como o $\alpha$-patcholeno, $\alpha$-copaeno e o $\alpha$-muuroleno, e numerosos alcanos de cadeia linear) como, por exemplo, de azeite. 


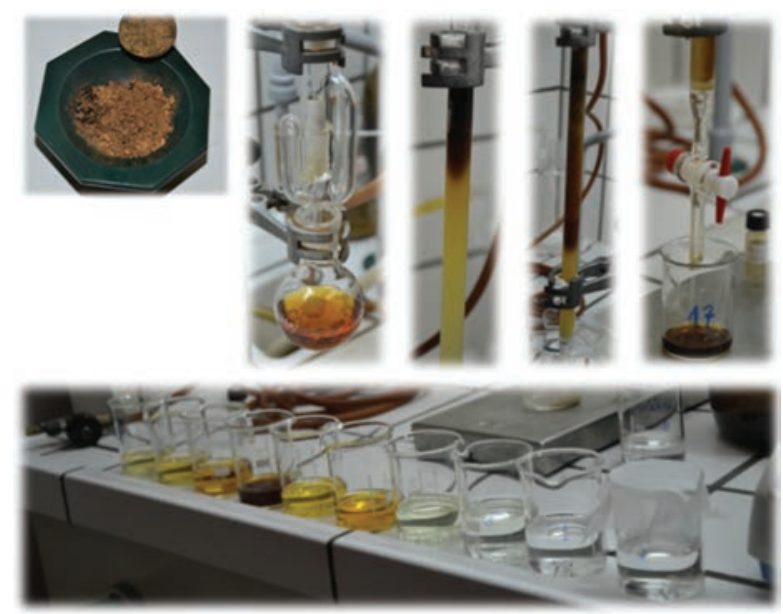

Figura 7 - Pormenor do procedimento de extracção do resíduo orgânico da ânfora tipo Haltern 70: pulverização da amostra em almofariz de ágata (a), extracção em sistema Soxhlet (b) e cromatografia em coluna flash ((c) a (e)) com eluição de diferentes fracções de compostos (f)

\section{VINHO COM AZEITONAS?}

Estes resultados pareciam ser inconsistentes por indiciarem o transporte de azeitonas imersas em vinho, o que representaria uma mistura de matrizes orgânicas incompatíveis entre si à luz da experiência actual. Todavia, a reunião destes resultados químicos com informações históricas permitiu concluir tratar-se de azeitonas em conserva de vinho, ou oliva ex defructum, um produto de consumo frequente na época de Augusto. O defructum era um líquido doce obtido pela cozedura do mosto, que poderia ser comercializado como bebida, ingrediente de cozinha, ou utilizado como substituto do mel. Era também comercializado para fortalecer vinhos locais de qualidade inferior.

\section{E A ÂNFORA URCEUS?}

Nesta ânfora detectou-se um elevado número de compostos característicos de resíduos de vinho, com especial destaque para os ácidos tartárico e málico, assim como grande quantidade de hidratos de carbono, sugerindo a fortificação do vinho com produtos açucarados, como por exemplo, mel. É conhecido o hábito da época de Augusto de se adicionar mel ao vinho para o tornar mais doce [12,13], podendo este procedimento explicar a anormal diversidade de hidratos de carbono encontrada no fragmento de ânfora Urceus. Um outro facto curioso foi a detecção de levoglucosano, característico da queima de biomassa vegetal. Embora a sua presença pareça não ser compatível com a utilização desta ânfora enquanto recipiente destinado a vinho adocicado, pode dever-se à aplicação de fumo durante o processo de crestar as colmeias para delas retirar o mel. De facto, ainda nos nossos dias é vulgar fumigar-se as colmeias para acalmar as abelhas e as afastar, de forma a permitir um acesso mais seguro ao mel. Nesta altura, o levoglucosano e outros compostos provenientes da degradação térmica de materiais celulósicos terão sido emitidos para a atmosfera e impregnado o mel crestado. Estas conclusões foram mais tarde reforçadas com a análise de fragmentos cerâmicos de potes meleiros ${ }^{2}$ e colmeias. Nestes últimos (uma espécie de tubos cerâmicos estriados no interior e abertos nas duas extremidades) detectou-se colesterol, um lípido esteroide normalmente associado a resíduos de alimentos de origem animal, cuja presença é aparentemente incompatível com a utilização destes contentores enquanto colmeias cerâmicas. Esta detecção foi inicialmente atribuída a contaminação pós-deposicional ou à manipulação indevida dos fragmentos cerâmicos após desenterramento e limpeza. Esta primeira hipótese foi também suportada pela realização de análises cromatográficas a mel proveniente de origens geográficas distintas, não se tendo detectado quaisquer vestígios de colesterol nas amostras de mel fresco, nem após a sua desidratação acelerada durante três dias a $80^{\circ} \mathrm{C}$. Uma análise das diferentes formas das colmeias ancestrais e modernas (a forma ancestral é tubular enquanto a moderna é uma caixa com quadros de alça) permitiu concluir-se da existência de diferentes procedimentos para a extracção do mel. De facto, usando-se colmeias de caixa as alças são retiradas no período de cresta com perturbações reduzidas do enxame, minimizando a interacção com as abelhas obreiras e a abelha rainha. Na antiguidade, a forma tubular das colmeias provocaria a necessidade de espremer as colmeias para delas se retirar o mel (inclusive com a ajuda de água quente) matando neste processo parte das abelhas e larvas ainda no seu interior. Neste processo, o colesterol proveniente do corpo dessas abelhas e larvas [14] contaminaria o mel crestado.

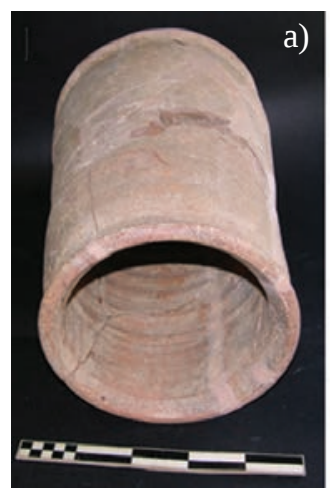

b)

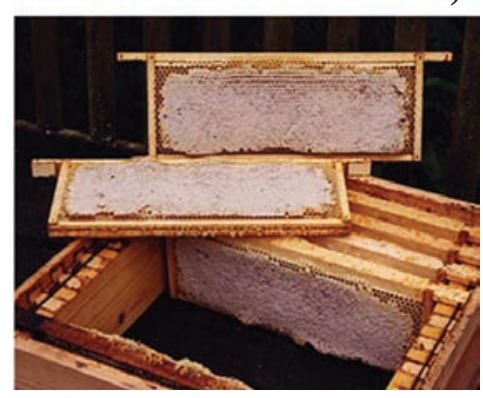

Figura 8 - a) colmeia cerâmica romana; b) colmeia de alças

\section{NovOS ACHADOS}

Recentemente (2014) o mar de Esposende colocou a descoberto vestígios arqueológicos de um naufrágio quinhentista de onde se recuperaram pratos em estanho e latão e duas dezenas de pelouros (balas de canhão em pedra). Encontrou-se na mesma praia algumas centenas de fragmentos de ânforas, maioritariamente da tipologia Dressel 7/11 bética, correspondentes a um naufrágio da época romana.

Os materiais cerâmicos estão já em estudo...

\footnotetext{
2 Recipientes com um ressalto muito saliente (mais raramente dois) em forma de aba ou "pestana”, frequentemente situado a cerca de um terço da parte superior do pote ou na proximidade da boca. Este tem a função de criar um canal de água em torno da parte superior do bojo para impedir que insectos como as formigas cheguem ao produto e, por outro lado, evitar que este escorra ao longo das paredes.
} 


\section{BIBLIOGRAFIA}

[1] R.P. Evershed, Archaeometry 50 (2008) 895-924

[2] M.P. Colombini, G. Giachi, F. Modugno, E. Ribechini, Microchem. J. 79 (2005) 83-90

[3] N. Garnier, C. Cren-Olive, C. Rolando, M. Regert, Anal. Chem. 74 (2002) 4868-4877

[4] H. Barnard, A.N. Dooley, G. Areshian, B. Gasparyan, K.F. Faull, J. Archaeol. Sci. 38 (2011) 977-984

[5] M.R. Guasch-Jane, M. Ibern-Gomez, C. Andres-Lacueva, O. Jauregui, R.M. Lamuela-Raventos, Anal. Chem. 76 (2004) 1672-1677

[6] F.R. Riley, Oxf. J. Archaeol. 21 (2002) 63-75

[7] A. Damascelli, F. Palmisano, Food Anal. Methods 6 (2013) 900-905

[8] R. Consonni, L.R. Cagliani, C. Cogliati, Food Control 32 (2013) 543-548
[9] A.P. Pereira, "Caracterização de mel com vista à produção de hidromel”, dissertação de mestrado em Qualidade e Segurança Alimentar, Escola Superior Agrária de Bragança, 2008

[10] M.W. Kujawski, J. Namieśnik, TrAC-Trend Anal. Chem. 27 (2008) 785-793

[11] X. Feás, J. Pires, A. Iglesias, M.L. Estevinho, Food Chem. Toxicol. 48 (2010) 3462-3470

[12] R. Morais, “Ânforas tipo urceus de produção Bética e produções regionais e locais do NW Peninsular”, Congresso Internacional CETARIAE 2005, Salsas y Salazones de pescado en occidente durante la Antiguedad, Cádis, 401415

[13] R. Morais, "Novos dados sobre as ânforas vinárias béticas de tipo urceus." SPAL, Revista de Prehistoria y Arqueología de la Universidad de Sevilla 17 (2008) 267-280

[14] M. Vanderplanck, D. Michez, S. Vancraenenbroeck, G. Lognay, Anal. Lett. 44 (2011) 1807-1820

\section{Actualidades Cientificas}

\section{LUZ VISÍVEL PROMOVE CATÁLISE ASSIMÉTRICA}

Em contraste com a grande variedade de sistemas catalíticos que estão disponíveis para controlar a estereoquímica de reacções de cicloadição promovidas termicamente, poucos métodos com eficácia similar existem para o controlo estereoquímico de reacções de cicloadição promovidas fotoquimicamente. Um grande desafio, ainda não solucionado, na concepção de reacções de fotocicloadição catalíticas enantiosselectivas tem sido a dificuldade de controlar a racemização que ocorre pela fotoexcitação directa de substratos ainda não coordenados ao catalisador.

Um grupo de químicos da Universidade de Wisconsin-Madison, EUA, desenvolveu uma estratégia para a eliminação do problema da racemização em reacções de fotocicloadição [2+2] assimétrica de cetonas $\alpha, \beta$-insaturadas, com formação dos correspondentes ciclobutanos, usando um sistema de catalisador duplo, um dos quais um fotocatalisador de um metal de transição que absorve luz visível, e um ácido de Lewis como co-catalisador estereosselectivo. A independência destes dois catalisadores permite maior alcance, maior flexibilidade estereoquímica e melhor eficiência do que os métodos de cicloadição fotoquímicos enantiosselectivos reportados até agora.

"Uma das razões para que este campo tenha falhado até agora é que um único catalisador teve que fazer ambos os papéis, ou seja, absorver a luz e controlar a quiralidade”, referiu Tehshik Yoon, um dos investigadores. "Modificando o catalisador único, alteram-se ambos os efeitos. Ao separar os dois papéis, pode-se fazer todo o tipo de alterações para promover a enantiosselectividade sem diminuir a capacidade do catalisador fotoquímico", concluiu.

Esta técnica pode ter importante impacto nos químicos sintéticos que procuram compostos enantiosselectivamente puros, nomeadamente no âmbito do desenvolvimento de fármacos.

(fontes: http://www.sciencedaily.com/releases/2014/04/140424143653.htm J. Du, K.L. Skubi, D.M. Schultz, T.P. Yoon, Science 344 (2014) 392-396, DOI: 10.1126/science.1251511)

Paulo Mendes (pjgm@uevora.pt)

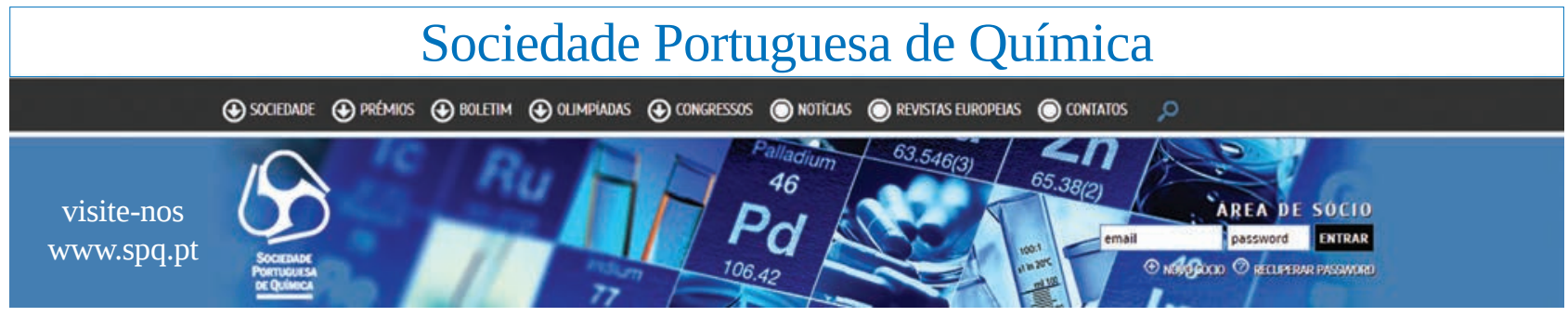

